Relations industrielles

Industrial Relations

\title{
Milkman, Ruth, editor, Organizing Immigrants: The Challenge for Unions in Contemporary California
}

\section{Jonathan Eaton}

Volume 55, numéro 4, 2000

URI : https://id.erudit.org/iderudit/051358ar

DOI : https://doi.org/10.7202/051358ar

Aller au sommaire du numéro

Éditeur(s)

Département des relations industrielles de l'Université Laval

ISSN

0034-379X (imprimé)

1703-8138 (numérique)

Découvrir la revue

Citer ce compte rendu

Eaton, J. (2000). Compte rendu de [Milkman, Ruth, editor, Organizing Immigrants: The Challenge for Unions in Contemporary California]. Relations industrielles / Industrial Relations, 55(4), 773-775.

https://doi.org/10.7202/051358ar

Tous droits réservés (C) Département des relations industrielles de l'Université Laval, 2000
Ce document est protégé par la loi sur le droit d'auteur. L'utilisation des services d'Érudit (y compris la reproduction) est assujettie à sa politique d'utilisation que vous pouvez consulter en ligne.

https://apropos.erudit.org/fr/usagers/politique-dutilisation/ 


\section{Recensions}

\section{Book Reviews}

\section{Organizing Immigrants: The Challenge for Unions in Contemporary California}

edited by Ruth MILKMAN, Ithaca, N.Y.: ILR Press, 2000, 260 pp., ISBN 08014-8617-3 (pbk.) and ISBN 0-8014-3697-4 (cloth).

Six decades ago, the American and Canadian labour markets were transformed when a generation of workers, many of them immigrants, organized entire industries to confront sweatshop conditions at work. Describing the apparel industry in 1938, Life magazine reported that: "Thirty years ago the industry stank of the sweatshop and the cruelest kind of exploitation... Still numerous in 1933, the sweatshop is virtually gone today" (As quoted in Global Standards \& the Apparel Industry, Conference Summary and Report, Harvard University, 1998, p. 1). Sweatshop abuses in the apparel and other industries were overcome, not through any natural evolution of the market, but because the growth of CIO-style industrial unionism allowed workers to win collective agreements to improve conditions and to lobby for worker protection laws to maintain minimum standards. That same year, speaking at the international convention of the Amalgamated Clothing Workers of America, union president Sidney Hillman stated: "Never have we been as strong numerically and as powerful in our influence as we are today. The [men's] clothing industry is 95 percent organized and hardly a half a dozen employers of any standing are not under contract with our organization.... Our influence for good in the industry will be felt even more in the years to come than it has been in the past" (quoted in Hardman, The Amalgamated - Today and Tomorrow, 1939, p. 9).
Read from the vantage point of the year 2000 , these statements seem hard to believe. The labour movement in North America now faces a crisis. For much of the last thirty years, union membership as a proportion of the workforce has been in freefall. In the United States today, only about one in ten private sector workers are union members. Although the crisis has been less pronounced in Canada than in the United States, here too union density has been shrinking.

The slide in union influence has paralleled and magnified a growing gap between rich and poor as middle-income blue-collar jobs "drift into history." As Harold Meyerson notes: "America has a new kind of structural poverty: the poverty of the employed. It is not cyclical, it is not a function of regional underdevelopment or individual pathology... It is the poverty that results from the normal working of the new economy even in boom times" ("Where's the Left? American Liberalism at Century's End," LA Weekly, March 19-25, 1999).

To confront this crisis, unions will have to come to grips with the new demographics of the labour market - to engage and organize the current generation of workers who toil in $21^{\text {st }}$ century sweatshops. This is the starting point of Organizing Immigrants: The Challenge for Unions in Contemporary California edited by Ruth Milkman. "[R]ecruiting immigrants is an increasingly urgent 
imperative for the besieged labor movement," she writes, noting that the swelling immigrant population, particularly in California, now provides the majority of workers in many low-waged manual jobs that were once the key strongholds of union organization. "Thus even recapturing formerly unionized territory - much less making inroads into newer sectors that have never been organized, where foreign-born workers also have a huge presence - requires the labor movement in California to confront the issue of immigration head-on" (p. 11).

The nine essays in the volume provide a revealing portrait of labour's struggle for survival and potential rebirth at the end of the $20^{\text {th }}$ century. The stage is set by two essays describing the new labour market reality in California. The demographic shift experienced in this state is astonishing. Nearly onequarter of the state's population and at least one-third of the workforce are foreign-born. Immigrant Latinos alone comprise 42 percent of California's factory workers and 49 percent of labourers. Most of the newcomers to the state are also non-white: Mexican-Americans and other Latinos will soon constitute the state's single largest ethic group and "Anglos" will become a minority. While California is at the vanguard as a port of entry for so many immigrants, the rest of the country will ultimately be affected by these changes.

The essays that follow track labour's efforts to organize the immigrant workforce in specific industries: hotel, garment, auto parts, residential construction and contract cleaning services. While the authors' support for the unions they studied is not in doubt, each case study is presented dispassionately, clearly portraying the strengths and weaknesses, the successes and failures in each campaign. A series of victories by immigrant workers in the early 1990 s - the successful organizing campaign at a large wheel manufacturing plant, the winning strike by drywallers in South- ern California and the celebrated "Justice for Janitors" campaign in Los Angeles - created the anticipation that labour was on the verge of a major breakthrough in immigrant organizing. But the wave has not yet come, and at the end of the decade the unions involved in these campaigns were struggling to hang on to the gains that they had won. For 150,000 mostly immigrant workers in the Los Angeles apparel industry, a "prototypically global industry" where employers can relocate production with relative ease, union organizing has hit a wall in spite of both truly appalling working conditions and significant organizing efforts by the Union of Needletrades, Industrial and Textile Employees.

In an essay that provides sharp insights for the labour movement, Rachel Sherman and Kim Voss take a hard look at what is required for unions to organize and win. They consider the question of why more unions are not adopting tactical innovations such as "rank and file intensive strategies" that focus on direct worker contact and worker participation, corporate campaigns and community coalitions. The reason, in a nutshell, is that these strategies require tremendous resources, and the structural and cultural changes that unions must undergo to find these resources are extremely difficult. Current union members must be persuaded to see a much higher percentage of their union dues spent on organizing: as the union shifts away from a focus on servicing, members must take on more of their own problems on the shop floor. And members themselves need to get involved in organizing on their own time. "This change requires directly challenging the old mentality of servicing, in which membership dues are paid in exchange for a union staff that... take care of members' problems for them" (p. 89). But union locals that have successfully navigated this transformation are able to utilize the full array of new 
organizing tactics and are thus in a position to grow, and ultimately secure stronger contracts for their members.

Organizing Immigrants provides a timely and coherent analysis of the key issue facing North American unions, and of some of the strategies that will allow us to meet this challenge.

JoNATHAN EATON

Union of Needletrades, Industrial and Textile Employees

\section{Steelworker Alley: How Class Works in Youngstown}

by Robert BRUNO, Ithaca, N.Y.: ILR Press, 1999, 222 pp., ISBN 0-8014-

3439-4 (cloth) and ISBN 0-8014-8600-9 (paper).

Like me, Robert Bruno is a college professor who grew up in a steelworker family during the era of union power, 1942-1982. In graduate school he learned that by the mid-1950s, about the time he was born, steelworkers in the U.S. had become thoroughly "middle class." Bruno, however, could not "connect what I later knew about middleclass prosperity and values with the way my parents lived," nor could he reconcile the "dissonance I felt between accepted doctrine and my own experiences." Steelworker Alley presents his case that the accepted doctrine is wrong and that steelworkers then and now share a working-class identity.

Combining a neo-Marxist framework borrowed from Ira Katznelson with sophisticated social science methods, Bruno interviewed 75 retired steelworkers from the Youngstown, Ohio, area and analysed neighbourhood census data and historical archives for the industrial borough of Struthers, where he grew up. Among his interviewees were his father and mother and many of their friends, neighbours and workmates. What results is both a poignant portrait and a compelling analysis of steelworkers who are not now nor have they ever been "middle class."

To Canadians this may seem a trivial exercise, but in the U.S. we are generally not permitted to speak of a "working class." During the Cold War it was more than faintly disloyal to do so, while today it is still not permissible unless you can supply a one-sentence definition that is immediately acceptable to middleclass professionals whose own culture is deeply committed to the idea that everybody but the "rich" and "poor" is exactly like them, only less so. Bruno supplies no such definition. Instead, with the aid of his interviews, he systematically looks at the workplace, neighbourhood, consumer, and local political lives of his interviewees to reveal a culture that is palpably different from standard conceptions.

In the end, Bruno found a way of life utterly devoid of the kind of acquisitive individualism, personal ambition, statusconsciousness and achievement-orientation characteristic of middle-class life. "In Youngstown," he concludes, "the working class... valued cooperation, mutual aid, collective work, common needs, personal dignity, and equality of condition." Furthermore: "Neighbors were expected to be cognizant of each other and provide mutual support, usually without being asked. A selfish act of individualism was the inglorious badge of a "scab," and human freedom was defined less by willed decisions than it was by acting in ways that preserved the past for the next generation. What steelworkers expressed through their relationships was nothing less than a nonexploitive way to live" (p. 162).

Is this a romanticization? I don't think so, but that may depend on which romance you favour. The working class Bruno presents is no revolutionary vanguard, nor even a soft-spoken opponent of capitalism. But it has what Bruno 